\title{
Pengaruh Metode Suku Kata Mengunakan Media Kartu Huruf terhadap Kemampuan Membaca Permulaan Siswa Kelas I SD Muhammadiyah Majaran Kabupaten Sorong
}

\author{
Shalatsi Havisa $^{1}{ }^{\circledR}$ Solehun $^{2} \&$ Teguh Yuliandri Putra ${ }^{3}$
}

\author{
Program Studi PGSD, Universitas Pendidikan Muhammadiyah Sorong, Indonesia \\ $\bowtie$ E-mail: shalatsihavisa1@gmail.com
}

\begin{abstract}
Abstrak
Penelitian ini dilakukan dengan tujuan untuk mengetahui pengaruh medote suku kata menggunakan media kartu huruf terhadap kemampuan membaca permulaan siswa kelas I SD Muhammadiyah Majaran Kabupaten Sorong. Penelitian ini merupakan penelitian eksperimen, dengan desain PreExsperimental Design. Populasi dalam penelitian ini adalah seluruh siswa SD Muhammadiyah majaran Kabupaten Sorong dengan sampel kelas I yang berjumlah 14 siswa. Instrumen yang digunakan dalam penelitian adalah lembar observasi siswa, RPP, instrument kemampuan membaca dan media kartu huruf. Data yang diperoleh pada penelitian selanjutnya diuji normalitas sebagai uji prasyarat untuk melakukan uji hipotesis.Uji hipotesis yang digunakan yaitu N-Gain dan One Sampel tTest. Hasil uji realibilitas soal pre test diperoleh Cronbach's Alpha sebesar 0.617 dan uji realibilitas soal post test sebesar 0,647. Berdasarkan hasil penelitian diperoleh nilai rata-rata pre test 58,93 dan nilai post test 80,86. Dari perhitungan One Sampel t-test diperoleh thitung $>$ ttabel yaitu 4,637>2,160 Sehingga dapat disimpulkan bahwa metode suku kata menggunakan media kartu huruf memberi pengaruh terhadap kemampuan membaca siswa dimana kemampuan membaca siswa menjadi meningkat.
\end{abstract}

Kata Kunci: Metode Suku Kata; Media Kartu Huruf; Kemampuan Membaca Permulaan.

\begin{abstract}
This research was conducted with the aim to determine the effect of syllable medote using letter card media on the beginning reading ability of first grade students of SD Muhammadiyah Majaran, Sorong Regency. This research is an experimental research, with a pre-experimental design. The population in this study were all students of SD Muhammadiyah Majaran, Sorong Regency with a sample of class I totaling 14 students. The instruments used in the study were student observation sheets, lesson plans, reading skills instruments and letter card media. The data obtained in the next study were tested for normality as a prerequisite test for conducting hypothesis testing. Hypothesis tests used were N-Gain and One Sample t-Test. The results of the reliability test of the pre-test items obtained by Cronbach's Alpha of 0.617 and the reliability of the post-test items of 0.647. Based on the results of the study, the pre-test average value was 58.93 and the post-test score was 80.86. From the calculation of the One Sample t-test, it is obtained tcount> ttable, namely 4.637> 2.160. So it can be concluded that the syllable method using letter cards media has an effect on students 'reading ability where students' reading ability increases.
\end{abstract}

Keywords: Syllable Method; Letter Card Media; Beginning Reading Ability. 


\section{PENDAHULUAN}

Membaca merupakan tahap awal anak dalam proses belajar membaca. Membaca permulaan sebagai keterampilan dasae mambaca bagi siswa dan alat bagi siswa untuk mengetahui pengetahuan (Syatauw, G.R., Solehun, S., \& Rumaf, N, 2020:80).

Membaca merupakan suatu kegiatan interaktif untuk mengambil serta memahami arti yang terkandung dalam bahan tulis (Somadoyo,2011:14). Kemampuan membaca sering menjadi masalah bagi guru dalam melaksanakan pembelajaran terutama di kelas I SD karena mayoritas siswa memiliki kemampuan membaca yang rendah. Membaca berpengaruh besar kepada kemampuan siswa dalam menerima materi pelajaran terutama pembelajaran berbasis teks, siswa yang tidak mampu membaca dengan baik akan mengalami kesulitan dalam mengikuti kegiatan pembelajaran semua mata pelajaran.

Menurut Rahim (2012:1) manfaat membaca antara lain membuat seseorang mendapat pengetahuan dan wawasan baru yang akan meningkatkan kecerdasan sehingga lebih dapat menjawab tantangan hidup. Budaya membaca merupakan cerminan kemajuan suatu masyarakat atau bangsa.Hal ini dibenarkan oleh Zuchdi (2012:17), yang menyatakan bahwa membaca dan menulis merupakan instrument utama dari tradisi keilmuan yang menjadi pemacu perubahan sebuah bangsa.Data hasil survey dari studi Most Littered Nation In the Wold yang dilakukan pada tahun 2016 menyatakan bahwa minat baca masyarakat Indonesia sangat rendah dibandingkan dengan negara lainnya. Dari 61 negara, Indonesia menempati urutan ke-60 terkait minat baca.

Data statistik UNESCO pada tahun 2012 menyatakan indeks minat baca di
Indonesia baru mencapai 0,001.Artinya dari 1000 penduduk hanya satu warga yang tertarik untuk membaca.Menurut indeks pembangunan pendidikan UNESCO ini, Indonesia berada di nomor 69 dari 127 negara. Programme For International Student Assessment (PISA) juga menempatkan Indonesia di nomor 57 dari 65 negara yang diteliti dalam hal kemampuan membaca siswa (www.republika.co.id). Hal ini tentu sangatlah memprihatinkan (Vuri, 2016). Papua dan Papua Barat merupakan provinsi dengan angka buta huruf tertinggi. UNESCO dan Kementerian pendidikan dan Kebudayaan di Tahun 2012 menyatakan bahwa terdapat $4,43 \%$ penduduk buta huruf di Indonesia, atau sekitar 6.730 .682 penduduk buta huruf, dengan variasi tingkat buta huruf antar provinsi. Terdapat empat provinsi yang memiliki tingkat buta huruf tertinggi, yaitu Nusa Tenggara Barat (16,48\%), Nusa Teggara Timur (10,13\%), Sulawesi Barat $(10,33 \%)$ dan Tanah Papua $(36,31 \%)$.

UNICEF et al. (2012) menganalisis adanya perbedaan tingkat buta huruf di wilayah pedalaman dan terpencil Papua dan Papua Barat, dibandingkan dengan daerah perkotaan. Di propinsi Papua, sekitar 37\% dari populasinya tinggal di dataran tinggi, $41 \%$ tinggal di kabupaten dataran rendah yang mudah dijangkau. Keluarga dan anak yang tinggal di wilayah pedalaman dan terpencil mengalami kesenjangan ekonomi dan pendidikan yang paling signifikan.Perbedaan signifikan terlihat pada tingkat literasi antara wilayah perkotaan dan pedalaman Papua, dimana tingkat buta huruf pada wilayah pedalamanlebih tinggi (49\%) dibandingan wilayah perkotaan (Nursalim \& Sudibyo, 2018).

Ada 2 faktor yang mempengaruhi kemampuan membaca siswa yaitu faktor 
internal dan faktor eksternal.Faktor internal salah satunya adalah motivasi.Faktor eksternal meliputi motode pembelajaran, bahan bacaan, dan media pembelajaran.

Pendidikan Anak Usia Dini lebih menekankan pada kegiatan bermain sambil belajar sehingga menciptakan pembelajaran yang menyenangkan. Melalui bermain, banyak konsep dasar dari pengetahuan mampu diperoleh seperti konsep dasar bentuk, ukuran, warna, serta arah yang termasuk dasar dari perkembangan bahasa (Ari Musodah, 2014).

Dikelas 1 SD pembelajaran mem-baca yang dialkukan adalah membaca permulaan. Metode pembelajaran mem-baca permulaan ada 5 yaitu: 1). Metode Eja, metode ini memulai pengajarannya dengan memperkenalkan huruf-huruf secara alfabetis. Huruf-huruf tersebut dihafalkan dan dilafalkan anak sesuai dengan bunyinya menurut abjad. Sebagai contoh A/a, B/b. C/c, $\mathrm{D} / \mathrm{d}, \mathrm{E} / \mathrm{e}, \mathrm{F} / \mathrm{f}$ dan seterusnya, dilafalkan sebagai (a), (be), (ce), (de), (ef) dan seterusnya, 2). Metode bunyi merupakan bagian dari metode eja, hanya saja dalam pelaksanaannya metode bunyi melalui proses latian dan tubian. Contoh : huruf $\mathrm{b}$ dilafalkan (eb), d dilafalkan (ed) dan seterusnya. 3). Metode suku kata juga disebut dengan metode silabel. Proses pembelajaran metode ini diawali dengan pengenalan suku kata, seperti : ba, bi, bu, be,bo, ca, ci, cu, ce, co, da, di, du, de, do, ka, ki, ku, ke, ko dan seterusnya. Suku- suku kata tersebut dirangkai menjadi kata-kata bermakna sebagai contoh : ba - ju, bi -bi, bo - la, ka - ki dan seterusnya. Kegiatan ini dapat dilanjutkan dengan proses perangkaian kata menjadi kalimat sederhana. 4). Metode kata adalah metode yang diawali dengan pengenalan kata yang bermakna fungsional, dan kontekstual. Sebaiknya dikenalkan dengan kata yang terdiri dari dua suku kata terlebih dahulu. 5). Metode global adalah cara belajar membaca kalimat secara utuh. Metode global ini didasarkan pada pendekatan kalimat.Caranya ialah guru mengajarkan membaca dan menulis dengan menampilkan kalimat di bawah gambar. 6). Metode Struktural Analitik Sintetik atau yang biasa disingkat dengan SAS merupakan salah satu metode yang dapat digunakan dalam pembelajaran membaca dan menulis permulaan.

Dari observasi singkat yang di lakukan peneliti di SD Muhammadiyah Majaran, dari 14 siswa kelas I hanya ada 4 siswa yang lancar membaca sedangkan siswa lain ada yang sudah mampu membaca kata tetapi harus di eja setiap hurufnya dan ada pula yang belum bisa menggabungkan huruf menjadi kata. Ada beberapa faktor yang menyebabkan siswa kelas 1 SD Muhammadiyah Majaran belum lancar membaca salah satunya yaitu penggunaan media pembelajaran yang kurang efektif. Melihat permasalahan tersebut peneliti berkeinginan meningkatkan kemampuan membaca permulaan siswa kelas I di SD Muhammadiyah Majaran menggunakan metode yang di sertai dengan media pembelajaran.Metode serta media yang di rasa cocok untuk siswa kelas I adalah metode suku kata dengan media kartu huruf.

Penelitian ini mengarah kepada hasil penelitian yang dilakukan oleh I Ketut Gading, Mutiara Magta, dan Fenny Pebrianti berjudul " Pengaruh Metode Suku Kata Dengan Media Kartu Kata Bergambar terhadap Kemampuan Membaca Permulaan anak di Taman Kanan-Kanak' Berdasarkan hasil penelitian terdapat pengaruh metode suku kata dengan media kartu kata bergambar terhadap kemampuan membaca permulaan anak di Taman Kanak-kanak. $(\mathrm{t}=$ 
2.466 ; 0.017). (Gading I Gusti, dkk 2019)

Penelitian yang relevan selanjutnya dilakukan oleh Darnis Arief yang berjudul" Pengaruh Penggunaan Media Kartu terhadap KemampuanMembaca Siswa Kelas I SDN 10 Lubuk Buaya Padang. Berdasarkan hasil penelitian dilihat dari pengucapan (lafal) skor tertinggi diperoleh 5 dan terendah 2, dengan rata-rata 3,59. Artinya, rata-rata siswa mampu mengucapkan kata dan kalimat dengan lafal yang tepat dan wajar. Skor ratarata aspek kelancaran yang diperoleh siswa adalah 3,64. Artinya adalah siswa dapat membaca dengan lancar, serta mampu merangkai huruf menjadi suku kata,suku kata menjadi kata.(Arief Darnis, 2014)

Persamaan penelitian oleh I Ketut Gading, dkk dengan penelitian yang akan dilakukan adalah sama-sama menggunakan metode suku kata dan menggunakan media kartu sedangkan penelitian oleh Darnis Arif sama-sama menggunakan media kartu .

Perbedaannya penelitian oleh I Ketut Gading, dkk menggunakan media kartu bergambar dan dilakukan pada tingkat sekolah taman kanak-kanak. Sedangkan penelitian yang akan dilakukan berfokus pada media kartu yang tidak bergambar, ada yang bergambar tetapi hanya sebagai penambah materi dan dilakukan pada tingkat sekolah dasar. Sedangkan Darnis Arief tidak menyebutkan metode pembelajaran yang digunakan sedangkan penelitian yang akan dilakukan menggunakan metode suku kata.

Menurut Mustikawati (2015) membaca permulaan merupakan tahapan proses belajar membaca bagi siswa sekolah dasar kelas Awal. Menurut Dewi (2017) Membaca permulaan adalah tahap awal anak dalam proses belajar membaca. Membaca permulaan sebagai keterampilan dasar membaca siswa dan alat bagi siswa untuk mengetahui makna dari isi mata pelajaran yang dipelajari di sekolah.Semakin cepat siswa dapat membaca makin besar peluang memahami isi makna mata pelajaran.

Metode suku kata merupakan penerapan pengenalan huruf kepada siswa yaitu merangkaikan suku kata menjadi huruf dan akhirnya menjadi kata, artinya mengungkapkan bahwa membaca merupakan suatu kesatuan kegiatan seperti mengenali huruf dan kata-kata, menghubungkannya dengan bunyi dan maknanya, serta menarik kesimpulan mengenai maksud jawaban.

Metode sangat berkaitan dengan media pembelajaran, pemilihan metode tentu akanmempengaruhi jenis media yang digunakan. Kata media berasal dari bahasa Latin medium yang artinya perantara atau pengantar. (Mahnun, 2012)

Media merupakan suatu alat atau sarana yang berfungsi sebagai perantara atau saluran, atau jembatan, dalam kegiatan komunikasi, antara komunikator (penyampai pesan) dan komunikan (penerima pesan) untuk menyampaikan informasi dalam situasi belajar mengajar. (Gading I Gusti, dkk 2019). Menurut Association for Education and Communication Technology (AECT), media merupakan segala bentuk dan saluran yang dipergunakan untuk proses informasi. National Education Association (NEA) mendefinisikan media sebagai segala benda yang dapat dimanipulasi, dilihat, didengar, dibaca atau dibicarakan beserta instrumen yang dipergunakan untuk kegiatan tersebut.dapat disimpulkan bahwa media adalah segala sesuatu yang dapat menyalurkan informasi dari sumber pemberi informasi ke penerima informasi.

Kartu huruf adalah kartu kecil yang berisi gambar, teks, atau tanda simbol yang dapat mengingatkan dan menuntun siswa kepada sesuatu yang berhubungan dengan gambar itu (Rahman \& Haryanto, 2014). 


\section{METODE PENELITIAN}

Jenis penelitian yang digunakan dalam penelitian ini adalah kuantitaif. Menurut Sugiyono (2018:14) penelitian kuantitatif dapat diartikan sebagai penelitian yang berlandaskan pada filsafat positivisme, digunakan untuk meneliti pada populasi atau sampel tertentu, teknik pengambilan sampel pada umumnya dilakukan secara random, pengumpulan data menggunakan instrument penelitian, analisis data bersifat kuantitatif/statistik dengan tujuan untuk menguji hipotesis yang telah ditetapkan.

Desain penelitian yang digunakan dalam penelitian ini adalah PreExsperimental Design yatu penelitian dilakukan pada satu kelompok eksperimen yang mendapat pengajaran menggunakan metode suku kata melalui kartu huruf. Menggunakan One Group Pretest - Posttest yaitu tes dilakukan sebanyak dua kali sebelum (Pre-test) dan sesudah diberi perlakuan (Post-test).Penelitian ini dilaksanakan di SD Muhammadiyah Majaran Kabupaten Sorong, Provinsi Papua Barat.

Populasi dalam penelitian ini yaitu seluruh siswa SD Muhammadiyah Majaran Kabupaten Sorong yang berjumlah 58 siswa. Untuk menentukan sampel digunakan teknik sampling.Teknik pengambilan sampel pada penelitian ini adalah purposive samping.Sampel dalam penelitian ini adalah siswa kelas 1 SD Muhammadiyah Majaran yang berjumlah 14 siswa. Teknik pengumpulan data meng-gunakan 2 cara yaitu observasi dan tes performace.

\section{Uji Prasyarat Analiis}

\section{Uji Validitas}

Validitas dilakukan dengan cara Expert Judgement (ahli uji) yaitu dosen bahasa Indonesia sebagai ahli. Yang menjadi ahli uji atau validator terdiri dari Noval Rumauf, M.Pd. sebagai penguji media kartu huruf.
Syams Kusumaningrum, S.S., M.Pd.I. sebagai penguji RPP, instrument tes membaca siswa, dan lembar observasi.

\section{Uji Reliabilitas}

Kriteria suatu instrument dikatakan reliable apabila hasil $>\alpha(0,6)$. Uji reliabilitas menggunakan SPSS 26.

\section{Uji Normalitas}

Untuk menguji apakah distribusi normal atau tidak dengan melakukan pengujian Shapiro-Wilk menggunakan SPSS 26.

\section{Uji Hipotesis}

1) Uji N-Gain

Tabel 1 Kriteria Nilai N-Gain

\begin{tabular}{|c|c|}
\hline Nilai N-Gain & Kriteria \\
\hline $\mathrm{N}-$ Gain $\geq 0,70$ & Tinggi \\
\hline $0,30<\mathrm{N}$-Gain $<$ & Sedang \\
\hline \multicolumn{2}{|l|}{0,70} \\
\hline $\mathrm{N}-$ Gain $\leq 0,30$ & Rendah \\
\hline \multicolumn{2}{|c|}{ Sumber: www.spssIndonesia.com } \\
\hline \multicolumn{2}{|c|}{ Tabel 2 Kategori Tafsiran Efektifitas N-Gain } \\
\hline Persentase & Tafsiran \\
\hline$<40$ & Tidak Efektif \\
\hline $40-55$ & Kurang Efektif \\
\hline $56-75$ & Cukup Efektif \\
\hline$>75$ & efektif \\
\hline
\end{tabular}

Sumber: www.spssIndonesia.com

Uji N-Gain menggunakan bantuan SPSS 26.

\section{Uji One Sampel t-Test}

Dasar pengambilan keputusan uji ini yaitu: H0 diterima jika signifikasi > 0,05 serta Thitung < Ttabel dan H1 diterima jika signifikasi $<0,05$ serta Thitung $>$ Ttabel

\section{HASIL DAN PEMBAHASAN}

Penelitian ini mengggunakan instrumen berupa RPP, Lembar Observasi, dan instrument tes membaca permulaan serta media kartu huruf. Sebelum dilakukan penelitian, instrument dan media terlebih dahulu dikonsultasikan dengan dua Expert Judgement (ahli uji). Kedua Ahli tesebut 
menyatakan bahwa instrument dan media yang telah dibuat layak untuk digunakan saat penelitian. Sebelum dilakukan pengujian hipotesis maka terlebih dahulu dilakukan pengujian validasi atau uji instrument dan pengujian reliabilitas pretes-postest kemudian selanjutnya dilakukan uji hipotesis. Berikut hasil uji reliabilitas dapat dilihat pada tabel 3 dan tabel 4;

Tabel 3. Hasil Reliabilitas Pre-Test

\begin{tabular}{r|r}
\hline \multicolumn{2}{c}{ Reliability Statistics } \\
\hline Cronbach's Alpha & N of Items \\
\hline .617 & 3
\end{tabular}

Berdasarkan perhitungan uji reliabilitas terhadap instrumen pre test menggunakan SPSS V26.0 diperoleh hasil Cronbach's Alpha untuk instrumen soal pre test sebesar 0,617 dan nilai ini lebih besar dari alpha yaitu 0,5 dimana $0,617>0,6$. Dengan demikian, instrumen Pre test tersebut telah memenuhi syarat reliable dan dapat digunakan untuk penelitian.

Tabel 4 Hasil Reliabilitas Post-Test

\begin{tabular}{r|r}
\hline \multicolumn{2}{c}{ Reliability Statistics } \\
\hline Cronbach's Alpha & N of Items \\
\hline .647 & 3 \\
\hline
\end{tabular}

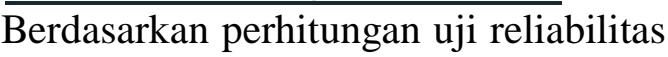
terhadap instrumen soal post test menggunakan SPSS V26.0 diperoleh hasil Cronbach's Alpha untuk instrumen soal sebesar 0,647 dan nilai ini lebih besar dari alpha yaitu 0,5 dimana 0,647>0,5. Dengan demikian, instrumen soal post test tersebut telah memenuhi syarat reliable. Analisis Deskriptif pre-test dapat dilihat pada tabel 5 berikut;

Tabel 5 .Nilai Pre-test dan posttest Kemampuan Membaca

\begin{tabular}{llcccc}
\hline No. & Nama Siswa & Nilai & Kategori & Post-Test & Kategori \\
\hline 1. & AFN & 67 & $\mathrm{C}$ & 83 & B \\
2. & AGR & 58 & $\mathrm{C}$ & 83 & $\mathrm{~B}$ \\
3. & AIRT & 67 & $\mathrm{C}$ & 100 & $\mathrm{~A}$ \\
4. & ADA & 75 & $\mathrm{~B}$ & 92 & $\mathrm{~A}$ \\
5. & ARM & 42 & $\mathrm{D}$ & 67 & $\mathrm{~B}$ \\
6. & CZ & 58 & $\mathrm{C}$ & 83 & $\mathrm{~B}$ \\
7. & MRR & 75 & $\mathrm{~B}$ & 100 & $\mathrm{~A}$ \\
8. & MSM & 67 & $\mathrm{C}$ & 83 & $\mathrm{~B}$ \\
9. & MUA & 58 & $\mathrm{C}$ & 75 & $\mathrm{~B}$ \\
10. & RRA & 58 & $\mathrm{C}$ & 75 & $\mathrm{~B}$ \\
11. & RDS & 50 & $\mathrm{C}$ & 75 & $\mathrm{~B}$ \\
12. & R & 42 & $\mathrm{D}$ & 58 & $\mathrm{C}$ \\
13. & WS & 58 & $\mathrm{C}$ & 75 & B \\
14. & YNA & 50 & $\mathrm{C}$ & 83 & A \\
\hline & Rata-rata & 58,93 & Cukup & 80,86 & Baik \\
\hline
\end{tabular}

Data nilai pretest dan posttest pada tabel 5 diatas menunjukkan bahwa perbedaan yang cukup signifikan antara pretest dan posttest. dari 14 siswa yang dijadikan sampel penelitian masih memperlihatkan nilai ratarata (mean) yang cenderung rendah. Nilai mean pre-test yang di peroleh siswa hanya
58,93 kategori Cukup dan post-test memperlihatkan nilai rata-rata yang meningkat dibanding dengan nilai pre-test. Nilai rata-rata (mean) post-test yang diperoleh siswa yaitu 80,86 kategori Baik

Berikut hasil rangkuman frekuensi distribusi nilai pretest dan postets 
berdasarkan tabel 5 dapat dilihat pada tabel 6 berikut;

Tabel 6. Data frekuensi pretest-postest

\begin{tabular}{ccccclll}
\hline \multirow{2}{*}{ No } & Nilai & \multicolumn{3}{c}{ Pre-test } & \multicolumn{3}{c}{ Post-test } \\
\cline { 3 - 7 } & KKM & Kategori & Frekuensi & Persentase (\%) & Kategori & Frekuensi & Persentase (\%) \\
\hline 1. & $>65$ & Mampu & 5 & $35,7 \%$ & Mampu & 13 & $92,8 \%$ \\
2. & $<65$ & Tidak & 9 & $64,3 \%$ & Tidak & 1 & $7,2 \%$ \\
& & Mampu & & & Mampu & & \\
\hline & & 14 & $100 \%$ & & 14 & $100 \%$ \\
\hline
\end{tabular}

Berdasarkan tabel 6 dapat di ketahui tailed) distribusi data yang diperoleh lebih bahwa frekuensi dan presentase nilai pre-test besar dari $\alpha=0,05$. Dapat disimpulkan hanya $5(43,3 \%)$ siswa yang mendapat nilai > 65 sedangkan siswa yang mendapat nilai < 65 sebanyak $9(64,3 \%)$ siswa maka dapat disimpulkan bahwa hanya 5 siswa yang berhasil mencapai kriteria ketuntasan minimum (KKM) sedangkan yang sisanya dikatakan tidak mampu.

Seangkan data frekuensi dan presentase nilai post-test terdapat $13(92,8 \%)$ siswa yang mendapat nilai > 65 sedangkan siswa yang mendapat nilai < 65 hanya 1 siswa maka dapat disimpulkan bahwa 13 siswa berhasil mencapai Kriteria Ketuntasan Minimum (KKM) dan 1 siswa tidak mencapai Kriteria Ketuntasan Minimum (KKM).

Selanjutnya hasil uji normalitas antara pretest dan posttest dapat dilihat pada tabel 7 berikut;

Tabel 7. Rangkuman hasil Uji Normalitas Tests of Normality

\begin{tabular}{l|r|r|r|}
\hline & \multicolumn{3}{|c|}{ Shapiro-Wilk } \\
\cline { 2 - 4 } & Statistic & \multicolumn{1}{|c|}{ Df } & \multicolumn{1}{c|}{ Sig. } \\
\hline Pretest & .927 & 14 & .273 \\
\hline Posttest & .933 & 14 & .339 \\
\hline
\end{tabular}

*. This is a lower bound of the true significance. a. Lilliefors Significance Correction

Berdasarkan data dari tabel11, dapat diperoleh hasil bahwa nilai Shapiro-Wilk pada pre-test 0,927 dengan Sig 0,273 ini berarti data pre-test tersebut berdistribusi normal dan nilai Shapiro-Wilk pada post-test 0,933 dengan sig 0,339 yang berarti data post-test berdistribusi normal. Dari data tersebut dapat dilihat bahwa Asymp Sig (2bahwa Asymp Sig (2-tailed) distribusi data pre-test dan post-test pada masing-masing variabel normal sehingga dapat digunakan untuk uji hipotesis.

Setelah dilakukan uji normalitas maka dilakukan uji N-Gain menggunakan SPSS 26, diperoleh nilai mean statistic adalah 56,5811 dan nilai tersebut berada antara rentang nilai 56-76, nilai yang terletak antara 56-76 termasuk dalam kategori cukup efektif. Sehinga dapat disimpulkan bahwa Metode suku kata menggunakan media kartu huruf cukup efektif digunakan dalam proses pembelajaran membaca di kelas 1 .

Berdasarkan hasil Uji One Sample menggunakan SPSS 26 menunjukan bahwa nilai thitung sebesar 4,637. Selanjutnya adalah tahap mencari ttabel, dimana ttabel di cari berdasarkan nilai df (degree of freedom atau derajat kebebasan) dan nilai signifikansi $(\alpha / 2)$. Dari data di atas di ketahui nilai df adalah n-1 yaitu $14-1=13$ dan nilai $0,05 / 2=$ 0,025 . Nilai tersebut di gunakan sebagai dasar acuan dalam mencari nilai ttabel pada distibusi nilai ttabel statistik (terlampir), maka nilai ttabel sebesar 2,160.

Berdasarkan data tersebut terlihat thitung > dari ttabel yaitu 4,637>2,160 sehingga $\mathrm{H} 1$ diterima $\mathrm{H} 0$ ditolak, sehingga dapat di simpulkan bahwa ada pengaruh metode suku kata menggunakan media kartu huruf terhadap kemampuan membaca permulan siswa kelas 1 SD Muhammadiyah 
Majaran.

Berdasarkan hasil penelitian yang dilakukan di SD Muhammadiyah Majaran Kabupaten Sorong, sampel yang digunakan untuk penelitian ini adalah siswa kelas I dengan jumlah 14 siswa. Penelitian ini merupakan penelitian eksperimen oleh sebab itu sebelum responden diberi perlakuan terlebih dahulu diberikan pre-test untuk melihat hasil awal kemampuan membaca siswa, setelah itu siswa diberi perlakuan yaitu membaca dengan metode suku kata menggunakan kartu huruf yang dilakukan selama 6 kali pertemuan. Setelah perlakuan selesai siswa diberikan post-test untuk melihat hasil apakah ada pengaruh dari perlakuan. Dari hasil pre-test diperoleh hasil mean sebesar 58,93 dan hasil mean post-test sebesar 80,86.

Berdasarkan pengolahan data uji normalitas menggunakan aplikasi SPSS 26 diperoleh hasil signifikasi data pre-test sebesar 0,273 dan 0,273>0,05 berarti data pre-test berdistribusi normal, sedangkan data post-test diperoleh hasil sebesar 0,339 dan $0,339>0,05$ sehingga post-test berdistribusi normal. Kedua data berdistribusi normal maka dapat melakukan uji selanjutnya yaitu uji hipotesis.Uji hipotesis dilakukan dengan uji one sampel t-test, namun sebelum uji one sampel t-test dilakukan uji N-Gain terlebih dahulu.Uji N-Gain dilakukan untuk melihat keefektifan metode suku kata menggunakan media kartu huruf. Hasil uji N-Gain menunjukkan bahwa rata-rata nilai post-test sebesar 80,86 jauh lebih tinggi dibandingkan nilai pre-test yaitu sebesar 58,93 .Jika dilihat dari nilaiefektivitas $\mathrm{N}$-Gain diperoleh hasil sebesar 56,58 kategori tafsiran efektifitas $\mathrm{N}$ Gain nilai yang terletak antara rentang 56 75 termasuk dalam kategori cukup efektif.

Setelah uji N-Gain tahap selanjutnya adalah uji One Sampel t-test, hasil penelitian diperoleh hasil thitung sebesar 4,637 nilai df pada penelitian n-1 yaitu $14-1=13$, nilai df 13 adalah 2,160 jadi thitung>ttabel yaitu $4,637>2,160$. Dari hasil uji one sampel ttest menunjukkan bahwa $\mathrm{H} 1$ diterima dan $\mathrm{H} 0$ ditolak artinya ada pengaruh metode suku kata menggunakan media kartu huruf terhadap kemampuan membaca permulaan siswa kelas I SD Muhammadiyah Majaran Kabupaten Sorong. Hasil ini juga didukung oleh peneliti yang lain, (Kambu, 2019 ; 43) menyimpulkan bahwa enggunaan media kartu huruf dapat meningkatkan keaktifan dan kreativitas siswa pada saat pembelajaran bahasa Indonesia.

\section{KESIMPULAN}

Berdasarkan rumusan masalah dan hipotesis yang diajukan, hasil analisis hipotesis dan pembahasan penelitian eksperimen pada pembelajaran membaca dengan metode suku kata menggunakan kartu huruf pada siswa kelas I SD Muhammadiyah Majaran Kabupaten Sorong maka dapat dikemukakan simpulan penelitian sebagai berikut:

Terdapat perbedaan mean (nilai ratarata) antara nilai pre-test dan post-test. Dari perhitungan diperoleh nilai mean pre-test sebesar 58,93 dan nilian mean post-test sebesar 80,86 berdasarkan nilai pretest dan nilai posttest ini dapat diambil kesimpulan bahwa dengan metode suku kata menggunakan media kartu huruf dapat mempengaruhi kemampuan membaca siswa.

Metode suku kata menggunakan media kartu huruf terbukti cukup efektif dan memiliki pengaruh terhadap kemampuan membaca siswa SD Muhammadiyah Majaran Kabupaten Sorong hal ini dibuktikan dengan uji N-Gain, dari hasil perhitungan diperoleh nilai efektifitas sebesar 56,58 dan nilai ini terletak antara rentang nilai $56-75$. 
Berdasarkan kategori tafsiran efektifitas NGain nilai yang terletak antara rentang 56 75 termasuk dalam kategori cukup efektif.

Metode suku kata menggunakan media kartu huruf terbukti cukup efektif dan memiliki pengaruh terhadap kemampuan membaca siswa SD Muhammadiyah Majaran Kabupaten Sorong. Dari perhitungan One Sampel t-test diperoleh thitung $>$ ttabel yaitu 4,637>2,160 Sehingga dapat disimpulkan bahwa H0 ditolak dan H1 diterima atau metode suku kata menggunakan media kartu huruf memberi pengaruh terhadap kemampuan membaca siswa dimana kemampuan membaca siswa menjadi meningkat.

\section{DAFTAR RUJUKAN}

Arif, D. (2014). Pengaruh Penggunaan Media Kartu terhadap Kemampuan Membaca Siswa Kelas I SDN 10 Lubuk Buaya Padang. Jurnal Al-Ta'lim.

Ari, M. (2014). Peningkatan Kemampuan Membaca Permulaan Melalui Media Kartu Kata Bergambar Pada Anak Kelompok B2 Ra Ma'arif $\mathrm{Nu}$ karang Tengah Kertanegara Puralingga.

Dewi, L. P. R., Sudarma, I. K., \& Suwatra, I. I. W. (2017). Pengaruh Metode Global Berbantuan Media Kartu Huruf terhadap Keterampilan Membaca Permulaan Kelas I SD. MIMBAR PGSD Undiksha, 5(2).

Gading, I. K., Magta, M., \& Pebrianti, F. (2019). Pengaruh Metode Suku Kata Dengan Media Kartu Kata Bergambar Terhadap Kemampuan Membaca Permulaan. Mimbar Ilmu, 24(3), 270276.

Haryanto, dan Rahman, B. (2014). Peningkatan Keterampilan Membaca Permulaan Melalui Media Flashcard Pada Siswa Kelas I Sdn Bajayau Tengah 2 Improving. Jurnal Prima Eduasia.

Kambu, Y. (2019). Peningkatan Kemampuan Baca pada Siswa Kelas 2 SD Negeri 6
Klablim Kota Sorong melalui Media Kartu Huruf. Jurnal Papeda: Jurnal Publikasi Pendidikan Dasar,1(1), 3644.

Mahnun, N. (2012). Media Pembelajaran. Jurnal Pemikiran Islam. Sidoarjo: Nizamia Learning Center).

Muhson, A. (2010). Pengembangan Media Pembelajaran Berbasis Teknologi Informasi.Jurnal Akuntansi Indonesia.

Mustikawati, R. (2015). Upaya Peningkatan Keterampilan Membaca Permulaan dengan Metode Suku Kata Pada Siswa Kelas I SD Negeri Nayu Barat Banjarsari Surakarta Tahun2014/2015. Jurnal Ilmiah Mitra Swara Ganesha.

Nursalim, dan Sudibdo, D. (2018).Pengembangan Egra Untuk Mengukur Kemampuan Baca Tulis Siswa Sd Kelas Awal Di Daerah Pinggiran Dan Terpencil 30 Sekolah Dasar Kabupaten Sorong. Jurnal ABDIMASA Pengambdian Masyarakat.

Rahim, Farida. (2012). Pengajaran Membaca di Sekolah dasar.Jakarta : PT. Bumi Aksara.

Sugiyono. (2018). Metode Penelitian Pendidikan Pendekatan Kuantitatif, Kualitatif dan $\mathrm{R} \&$ D. Bandung: Alfabeta,cv.

Somadoyo, Samsu. (2011). Strategi dan Teknik Pembelajaran Membaca. Yogyakarta: Graha Ilmu.

Syatauw, G.R., Solehun, S., \& Rumaf, N. (2020). Peningkatan Kemampuan Membaca Permulaan melalui Permainan Kartu Huruf Mata Pelajaran Bahasa Indonesia di Sekolah Dasar. Jurnal Papeda: Jurnal Publikasi Pendidikan Dasar, 2 (2), 80-86.

Vuri, D. (2016). Penerapan Pendekatan Pengalaman Berbahasa Dalam Pembelajaran Bahasa Di Sekolah Dasar Kelas Rendah.Jurnal Ilmiah Guru.

Zuchdi, Darmiyati. (2012). Strategi Meningkatkan Kemampuan membaca (Peningkatan Komprehensi). Yogyakarta: UNY Pres. 